\title{
JUSTINE THOMPSON
}

In recent years, we have made great progress in making the promise of rights a reality, but in doing so we have neglected another part of our inheritance-the vision of a republic where citizens actively take responsibility for maintaining a vital political life. ${ }^{1}$

\section{Mary Ann Glendon}

[T] he public, and perhaps the profession itself, seem increasingly convinced that lawyers are simply a plague on society. ${ }^{2}$

Geoffrey C. Hazard, Jr.

\section{INTRODUCTION}

For many Americans, it would be difficult to imagine a nation without lawyers. Corporate America would be unable to function without lawyers, television would not be the same without "L.A. Law," and accident victims would have no "800" numbers to call when seeking to redress their injuries. Although few would disagree with the proposition that American pop culture could survive without "L.A. Law," it is clear that lawyers are an integral component of modern American society. Lawyers influence the way Americans live, work, and argue. Lawyers even influence the way Americans talk. ${ }^{3}$

1. Mary ann Glendon, Rights talk: The impoverishment of Political DiscoURSE 17 (1991); see also Martha Minow, Interpreting Rights: An Essay for Robert Cover, 96 YALE L.J. 1860, 1862 (1987) (noting that "some . . charge that the preoccupation with rights is an illness in this society that prevents the development of social harmony"). (1991)

2. Geoffrey C. Hazard, Jr., The Future of Legal Ethics, 100 YALE L.J. 1239, 1240

3. GLENDON, supra note 1, at 1; see also infra Section I(A). 
America's fascination with lawyers, however, is accompanied by a widespread distrust of the legal profession. Whether deserved or not, the legal profession has been saddled with the societal perception that attorneys are greedy, opportunistic, and, above all, unethical. ${ }^{4}$ This negative perception of lawyers has not gone unnoticed in the legal community. As one scholar has noted, "[T]he legal profession is in crisis today. The public ... perceives lawyers as mean spirited, morally suspect, and ethically bankrupt." ${ }^{5}$ Nor does this negative reputation appear to be wholly undeserved. For instance, in a bar-sponsored pilot study, law students participated in a program that explored the effects of the law firm environment on the development of professional values. ${ }^{6}$ As part of the program, students working in law firms were required to furnish observations of attorney conduct in written journals. ${ }^{7}$ Of eighty-one journals, fifty-two included observations of flagrant misconduct, thirty of which included descriptions of multiple episodes, for a total of 107 episodes of misconduct. ${ }^{8}$ The events that occurred "did not present close questions where differing views could be debated"; these were cases where an attorney's conduct was recognized by the student writers to be patently wrong. ${ }^{9}$ Although the possibility always exists that a study may not perfectly reflect reality, the frequency and severity of the misconduct witnessed by these law students suggest a problem that cannot be ignored.

Considering the widespread occurrence of ethical misconduct, it is not difficult for legal scholars to agree that ethical problems exist in the legal community. However, it is an entirely different task to reach a consensus on how to solve the legal community's ethical problems. Proposals for improvement of the legal community's ethics are abundant. Some legal scholars believe that improved ethical training and preparation in legal education will increase the likelihood that lawyers will behave more ethically in

4. See Hazard, supra note 2, at 1240 .

5. David C. Olsson, Reporting Peer Misconduct: Lip Service to Ethical Standards Is Not Enough, 31 ARIz. L. REV. 657, 675 (1989). Complaints regarding the legal profession are hardly new. In fact, "[d]issatisfaction with lawyers is a chronic grievance, and inspires periodic calls for reform." Hazard, supra note 2, at 1239 (citations omitted).

6. Lawrence K. Hellman, The Effects of Law Office Work on the Formation of Law Students' Professional Values: Observation, Explanation, Optimization, 4 GEO. J. LEGAL ETHICS 537, 557 (1991).

7. Id. at $565-66$.

8. Id. at 583 .

9. Id. 
their professional practice. ${ }^{10}$ Some scholars advocate stronger peer review in the form of increased reporting by attorneys of misconduct. ${ }^{11}$ To others, the problem lies not in the educational system or in attorneys' willingness to report misconduct, but instead in how the legal community has chosen to regulate its attorneys. For instance, regulation of the legal profession, from requirements to practice law to standards of ethical behavior, has traditionally been "organized along generalist lines." 2 Thus, for some, the solution is to restructure ethical regulation in order to reflect specializations within the legal profession. ${ }^{13}$

Although many creative and promising proposals have been developed to improve ethics in the legal community, one particular theory deserves analysis. In Rights Talk: The Impoverishment of Political Discourse, Mary Ann Glendon explores how Americans engage in political dialogue and asserts that the content of this dialogue influences the behavior of individuals. ${ }^{14}$ In particular, she is concerned that American political dialogue fails to include the responsibilities that citizens may owe to one another. ${ }^{15}$ Glendon advocates the incorporation of responsibilities into America's mode of discourse, which, according to her theory, will lead to more responsible behavior. ${ }^{16}$ Although Glendon's theory focuses on the manner in which people communicate, she also perceives the role of the judiciary as integral in shaping individual behavior. In particular, in those instances when the law is silent or communicates the absence of moral or ethical obligations, she advocates that the judiciary respond by emphasizing the duty of citizens to act in a responsible manner. ${ }^{17}$

This Note explores whether Glendon's theory offers a solution to the ethical problems facing the legal community and whether a

10. See Ronald M. Pipkin, Law School Instruction in Professional Responsibility: A Curricular Paradox, 2 AM. B. Found. Res. J. 247, 266 (1979).

11. See M. Reece Smith, Jr., Peer Review: Its Time Has Come, 66 A.B.A. J. 451 (1980).

12. F. Raymond Marks \& Darlene Cathcart, Discipline Within the Legal Profession: Is It Self-Regulation?, 1974 U. ILL. L.F. 193, 236.

13. Id. ("The law license is a generalist license. Yet claims are made that the skills are specialized. If the profession remains formally organized along generalist lines, it is possible that any scheme of review of performance is doomed to failure.").

14. GLENDON, supra note 1 , at 171.

15. Id.

16. Id.

17. Id. at 84 . 
responsibility-based approach would encourage ethical conduct among attorneys. In order to determine the practical applicability of Glendon's theory, the analysis focuses on a distinct ethical problem: the ethical dilemma faced by an in-house counsel upon discovering that her client has committed an act of misconduct. Part I provides an overview of Glendon's responsibility-based approach and also examines the dilemma faced by the attorney serving as in-house counsel. Part II explores the extent to which Glendon's analysis can determine the appropriate judicial response that would most likely encourage in-house counsel to engage in ethical behavior, that of the Illinois Supreme Court in Balla v. Gambro, Inc. ${ }^{18}$ or that of the California Supreme Court in General Dynamics Corp. v. Rose. ${ }^{19}$ Part III reveals that application of Glendon's theory alone does not indicate whether the holding of Balla or General Dynamics would most likely encourage in-house attorneys to behave responsibly. Despite many powerful insights, Glendon's theory fails to provide tangible guidelines both to courts and individuals, and also fails to consider the social context of ethical decisionmaking by individuals attempting to resolve ethical conflicts. And without more guidance, it is unlikely that the legal community will be successful in its efforts to improve the ethics of its attorneys.

\section{BACKGROUND}

\section{A. Responsibility-Talk and Ethical Decisionmaking}

Glendon begins Rights Talk by commenting on the pervasiveness of law in American society: "Americans today, for better or worse, live in what is undoubtedly one of the most law-ridden societies that has ever existed on the face of the earth." ${ }^{20}$ Glendon perceives this highly legalistic culture as having a profound impact on the United States. In terms of its direct effect, the percentage of those involved in legal careers is unsurpassed in our history. ${ }^{21}$ Moreover, the law has a tremendous indirect impact on those not involved in the law. Irrespective of class or background,

18. Balla v. Gambro, Inc., 584 N.E.2d 104 (Ill. 1991).

19. GeneraI Dynamics Corp. v. Rose, 876 P.2d 487 (CaI. 1994) (en banc).

20. GLENDON, supra note 1 , at 2 .

2I. Id. 
Glendon asserts, Americans are consciously and unconsciously affected by the law. ${ }^{22}$

Although the effect of the "'legalization' of popular culture" ${ }^{23}$ can be seen throughout society, Glendon focuses on the impact of the law on how people talk and, in particular, on how people incorporate legalism into political dialogue. ${ }^{24}$ According to Glendon, Americans discuss the issues that concern them within a legalistic framework. Although she admits that the influence of the law on how Americans communicate is hardly a new phenomenon, ${ }^{25}$ Glendon expresses concern about what she perceives as a shift in the nature of this legalistic dialogue. She has noticed an "increasing tendency to speak of what is most important to us in terms of rights, and to frame nearly every social controversy as a clash of rights." ${ }^{26}$ Thus, Glendon concludes that Americans today are engaged in the exchange of "rights talk." 27

Glendon believes that the dialogue of rights talk is hindering the positive development of American society. She notes that "our rights talk, in its absoluteness, promotes unrealistic expectations, heightens social conflict, and inhibits dialogue that might lead toward consensus, accommodation, or at least the discovery of common ground." ${ }^{28}$ This concentration on rights has rendered American political dialogue combative, which in turn narrows the range of possible solutions to society's ailments. As one scholar has commented, rights talk is self-centered and makes collective

22. Id.

23. Id. at 3 .

24. Id.

25. Glendon recounts de Tocqueville's visit to the United States in the early 1800s. De Tocqueville observed that lawyers' habits and modes of discourse "infiltrate[d] throughout society right down to the lowest ranks." Id. at 1 (quoting 1 ALEXIS DE TOCQUEVILlE, DEMOCRACY IN AMERICA 270 (J.P. Mayer ed. \& George Lawrence trans., 1969)). According to de Tocqueville, the law and lawyers "left an unusually strong imprint on the 'manners and morals' of the new nation." Id. at 2. Although the influence of legal discourse on American society is not new, the level of that influence has dramatically increased. Where Abraham Lincoln was "equally at home with the Bible and Blackstone," politicians today rely primarily on legalism. Id. at 3 .

26. Id. at 4 .

27. Id. at 3.

28. Id. at 14. 
action increasingly difficult. ${ }^{29}$ Succinctly stated, "[r]ights alone do not make a good society." ${ }^{30}$

The problem with rights talk is not limited to its power to heighten social conflict and reduce cooperation. Glendon's greatest concern appears to be not what rights talk incorporates, but what it excludes. "Our rights-laden public discourse easily accommodates the economic, the immediate, and the personal dimensions of a problem," she writes, "while it regularly neglects the moral, the long-term, and the social implications." ${ }^{31}$ Glendon stresses that rights talk is missing the language of responsibility. And for Glendon, it is the language of responsibility that has the potential to mend some of the problems inherent in our rights-based society.2 As Thomas Barton has noted, "Professor Glendon has given us what rights talk does not: an invitation to a dialogue of accommodation and responsibility"; $; 3$ it is through such a dialogue that American society will be able to begin to solve many of its problems.

An example of the applicability of Glendon's concerns can be seen within the context of the legal community. Unlike the law in most European countries, American jurisprudence does not recognize a duty to aid a fellow human being who may be in danger. ${ }^{34}$

29. David Abraham, Are Rights the Right Thing? Individual Rights, Communitarian Purposes and America's Problems, 25 CONN. L. REV. 947, 953 (1993) (reviewing GLENDON, supra note 1) ("Worse yet, rights campaigns produce negative synergy: every campaign for rights inevitably elicits claims of counter-rights so that potential social solidarity gives way to individual absolutism, group egotism, and the disappearance of social obligation.").

30. Id. at 950. "If nothing else, the title of Glendon's book is directly on the mark. Trapped in a battle for rights, the dominant strand of social activism in America has failed to transcend . . . the inequalities lying at its heart and in its soul." Id. at 952.

31. GLENDON, supra note 1, at 171. As Thomas Barton noted,

Glendon properly calls our attention to the shallowness of rights talk, to the way it exacerbates antagonism, and to its role in the continuing impoverishment of our political dialogue. She understands that, despite our denials and blustering protestations of self-sufficiency, modern life makes us all mutually dependent. She is right to call for greater individual responsibilities; and she is right to ask us to recognize that freedom and equality cannot long endure a rhetoric focused only on winning.

Thomas D. Barton, Reclaiming Lasv Talk, 81 CAL. L. REV. 803, 814-15 (1993) (reviewing GLENDON, supra note 1).

32. GLENDON, supra note 1 , at 76 .

33. Barton, supra note 31 , at 814 .

34. GLENDON, supra note 1 , at 77 ; id. at 79 ("[N]o matter how strongly our moral sentiments might dictate a response, a person has no legal duty to rescue a 'stranger.' "); see also Abraham, supra note 29, at 956 ("[Legal education] emphasizes the absence of 
For many lawyers, examination of this doctrine has constituted a distimctive and memorable part of their legal education:

As part of the process through which young men and women are socialized into the legal profession, they have entered into the mental horizon of many American public officials. Year in and year out, all over the country, in a kind of initiation rite, firstyear law students have been challenged by their professors of torts or criminal law to come up with a theory to support legal redress against the swimmer who watches while the toddler drowns. . . . One by one, their ideas are shot down. ${ }^{35}$

In classroom dialogue, law students are explicitly taught to disregard the moral responsibility one may otherwise owe another. Because the dialogue focuses on an individual's rights, an individual faced with the choice of either helping someone in need or asserting her right to refrain from rendering aid may be more likely to choose the latter course of action.

In response to what she perceives as the negative impact of the duty to rescue doctrine, Glendon's theory advocates the incorporation of responsible language into the dialogue. In particular, this language should be included in legal discourse. According to Glendon, "What is more likely to surprise and disappoint an average citizen is the sense that the law appears to condone particularly shocking forms of anti-social behavior: failures to warn, or act, or summon aid." ${ }^{36}$ Thus, she advocates that the law, and the language surrounding that law, should focus not on the right to be free from the duty, but on the affirmative duty of an individual to help another. ${ }^{37}$ By shifting the focus to include responsibility, individuals would be more likely to aid those in need.

obligation to others. ... As every law student is taught, we have no legal duty to rescue a stranger unless we ourselves caused the peril he faces.").

35. GLENDON, supra note 1 , at 80 .

36. Id. at 83-84 (emphasis added).

Whether meant to be or not, law is now regarded by many Americans as the principal carrier of those few moral understandings that are widely shared by our diverse citizenry.... The absence of a legal obligation to come to the aid Id. at 87.

of another in peril can begin to miseducate a public ....

37. Id. at 101. 


\section{B. In-House Counsel and the Client}

If Glendon's analysis is correct, her theory may be applied to other circumstances as well. For instance, in the context of this Note, Glendon's theory could aid an attorney in making the responsible choice when that attorney has discovered misconduct by a client. Moreover, a responsibility-based approach could help courts determine what judicial response would most likely encourage individuals to take an affirmative act in fulfilling one's ethical responsibilities.

1. The Dilemma of Reporting a Client's Unethical Conduct. Historically, attorneys have served the public in a variety of roles, from sole practitioners and attorneys for the government to meinbers of established law firms. In addition to these more traditional roles, many attorneys have chosen to serve as in-house counsel for corporate clients. In recent years, the number of attorneys serving as in-house counsel has increased dramatically: "According to a study conducted in the early 1980's, 50,000 lawyers were on corporate payrolls, a figure double that of 15 years earlier; a more recent survey indicates that more than 10 percent of all lawyers in the United States are employed in-house by corporations." 38 Based on the sheer numbers of attorneys serving in these roles, the impact of in-house counsel on corporate America could be profound. Moreover, in-house counsel "affect the full range of corporate decisions." ${ }^{39}$ Thus, choices made by in-house counsel may have effects that go well beyond the . confines of the corporate legal department.

While serving as in-house counsel, an attorney is obligated to fulfill a number of responsibilities. The scope of these responsibilities is delineated in the Model Rules of Professional Conduct (Rules). ${ }^{40}$ The requirements outlined in the Rules frequently encompass activities involving the attorney-client relationship. For example, in-house counsel may not "reveal information relating to

38. General Dynamics Corp. v. Rose, 876 P.2d 487, 491 (Cal. 1994) (en banc) (citing CHARles W. WolfRAM, MODERN LeGal ETHICS $\$ 13.7 .3$ (1986)).

39. Grace M. Giesel, The Ethics or Employment Dilemma of In-House Counsel, 5 GeO. J. Legal ETHICS 535, 544 (1992).

40. MODEL RULES OF PROFESSIONAL CONDUCT (1991). Thirty-one states have adopted these Rules in some form. See 2 Geoffrey C. HAZARD, JR. \& William Hodes, THE LAW OF LAWYERING: A HANDBOOK ON THE MODEL RULES OF PROFESSIONAL CONDUCT 865 (Supp. 1989). 
representation of a client" without the consent of that client. ${ }^{41}$ The duties owed to a client clearly do not stop with the protection of attorney-client confidences. For instance, if an attorney knows that "an officer, employee or other person associated with the organization" intends to violate a legal obligation to the corporation, or violate a law that could reasonably be imputed to the organization, the lawyer "shall proceed as is reasonably necessary in the best interest of the organization." ${ }^{42}$ Of course, the responsibilities of an attorney, whether in-house or not, also include duties to the legal profession and to the public at large. As stated in the preamble to the Rules, an attorney must always fulfill her responsibilities as "an officer of the legal system and a public citizen having special responsibility for the quality of justice." ${ }^{43}$

One of the more controversial ethical responsibilities imposed on in-house counsel is the reporting requirement. The Rules permit an attorney, at her discretion, to report misconduct of a client in order to prevent the commission of a criminal act likely to result in death or serious bodily injury. ${ }^{44}$ Some states, however, have chosen not to follow the Model Rules of Professional Conduct and have eliminated the discretionary element of the reporting requirement. For instance, in Illinois, an attorney must report privileged information if it is necessary to prevent criminal activity that may result in death or serious bodily injury. ${ }^{45}$ Moreover, the

41. Model Rules of Professional Conduct Rule 1.6(a) (1991).

42. Id. Rule 1.13.

43. Id. Preamble.

44. See id. Rule $1.6(\mathrm{~b})$. The full text of Rule 1.6 provides:

(a) A lawyer shall not reveal information relating to representation of a client unless the client consents after consultation, except for disclosures that are impliedly authorized in order to carry out the representation, and except as stated in paragraph (b).

(b) A lawyer may reveal such information to the extent the lawyer reasonably believes necessary:

(1) to prevent the client from committing a criminal act that the lawyer believes is likely to result in imminent death or substantial bodily harm; or

(2) to establish a claim or defense on behalf of the lawyer in a controversy between the lawyer and the client, to establish a defense to a criminal charge or civil claim against the lawyer based upon conduct in which the client was involved, or to respond to allegations in any proceeding concerning the lawyer's representation of the client.

45. See Balla v. Gambro, Inc., 584 N.E.2d 104, 109 (IIl. 1991) ("A lawyer shall reveal information about a client to the extent it appears necessary to prevent . . . death or serious bodily injury." (citing ILL. R.P.C. 1.6(b))); In re Himmel, 533 N.E.2d 790, 793 (III. 1988) (citing ILL. R.P.C. 103(a), which states that a lawyer "shall" report certain misconduct). The states in which reporting is required are Arizona, Connecticut, Illinois, 
courts rigorously enforce the reporting requirements; if an attorney fails in her duty to report possible criminal violations or misconduct, the penalties can be severe and may even include suspension or disbarment. ${ }^{46}$ The controversial nature of this rnle, however, stems not from the mere existence of the reporting requirement, but from the consequences that follow compliance: many attorneys lose their jobs. ${ }^{47}$ While rigorous enforcement of the reporting requirement may benefit society by deterring undesirable client conduct, this benefit is extracted at the expense of the attorney.

An examination of the unique pressures that are present whenever an attorney serves as in-house counsel for one client reveals why the loss of an attorney's job is so controversial. In a large firm, the loss of a client may result in the loss of income. However, because in-house counsel typically serve only one client, the loss of that client will lead to a total loss of income. ${ }^{48}$ Thus, in-house counsel are unusually subject to financial pressures that a client may be able to exert. Moreover, "[t]he unfortunate plight of in-house attorneys is increasingly disturbing since their oneness with their employer-clients creates an atmosphere in which more improper requests may occur." 49 In addition to the possible financial implications of complying with the reporting requirements, the attorney may also be subject to peer pressure and divided loyalties. The attorney may be reluctant to report misconduct because she feels a sense of loyalty to a client whom she also considers a

Nevada, North Dakota, and Texas. STEPhen GILlers \& RoY D. Simon, JR., RegulATION OF LAWYERS: STATUTES AND STANDARDS 59 (1994).

46. See Balla, 584 N.E.2d at 109 (holding that in-house counsel do not "have a choice of whether to follow their ethical obligations as attorneys . . . or ... [the] unethical demands of their clients" and "must abide by the Rules of Professional Conduct"); In re Himmel, 533 N.E.2d at 796 (suspending attorney for one year for failure to report misconduct by client's former attorney).

47. See Balla, 584 N.E.2d at 106 (involving in-house counsel fired for insisting that client comply with FDA regulations); Mourad v. Automobile Club Ins. Ass'n, 465 N.W.2d 395, 397 (Mich. 1991), appeal denied, 478 N.W.2d 443 (Mich. 1991) (involving attorney fired for refusal to violate Code of Professional Conduct); Nordling v. Northern States Power Co., 478 N.W.2d 498, 500 (Minn. 1991) (involving attorney allegedly fired for objecting to a proposal to investigate personal lives of employees); Parker v. M \& T Chemicals, Inc., 566 A.2d 215, 218 (N.J. 1989) (involving attorney fired for refusing to join scheme to cheat competitor).

48. Giesel, supra note 39 , at 536 .

49. Id. at 547 ("The close identification of the attorney to the employer-client and its agents may blind the attorney to ethical issues or the employer-client may be able to persuade the attorney to ignore ethical issues."). 
friend. Moreover, the employer-client may consider the attorney to be "a friend and loyal member of the team"; $; 0$ a client feeling personally betrayed by the disclosure of confidential information by an attorney might subject that attorney to social ostracization. Thus, an attorney serving as in-house counsel may face the difficult choice of fulfilling her ethical obligations, thereby risking financial and emotional catastrophe, or complying with a client's unethical demands and risking suspension or disbarment.

Avoiding these pressures is virtually impossible because the client can take her business elsewhere. ${ }^{51}$ Moreover, an in-house attorney when faced with the difficult decision of reporting misconduct, is subject to the unique pressures of a corporate client that is not usually a nember of the Bar and thus has no legal responsibility to uphold the Rules. ${ }^{52}$ The likelihood that this scenario could occur is evident from studies on the ethics of the corporations themselves: "[I]t is not uncommon for large and respected corporations to commit crimes. Eleven percent of the largest 1000 American corporations were involved in bribery, fraud, price-fixing, or other crimes between 1970 and 1980." 53 In-house counsel may be facing the dilemina of choosing between ethical duties and job security inore often than most people may suspect.

2. A Solution for the Ethical Attorney. A potential solution to the dileinma facing in-house counsel following the discovery of unethical or illegal conduct by a client is to permit the attorney to sue her client if the client fires her for refusing to violate her ethical duties. ${ }^{54}$ By permitting a cause of action against the client, the attorney's financial losses are mitigated. Furthermore, the

50. Id.

51. William L. Hutton, Note, The Lawyer's Duty to Report Another Lawyer's Misconduct, 14 S. ILL. U. L.J. 683, 688 (1990) (citations ommitted):

Problems will occur, however, when clients take their business elsewhere to find a lawyer who will, at the clients' request, refrain from reporting the previous attorney's misconduct. If these clients' efforts are successful, then the profession's attempt to self-regulate will become a mockery. Therefore, unless the entire profession is induced to adhere strictly to the rule, it will be viewed as simply another obstacle to be avoided.

52. Ted Schneyer, Professional Discipline for Law Firms?, 77 CoRnell L. Rev. 1, 16 (1991).

53. Id. at 7 n.41 (citing Irwin Ross, How Lawless Are Big Companies?, ForTUNE, Dec. 1, 1980, at 56, 57).

54. See General Dynamics Corp. v. Superior Court, 876 P.2d 487 (Cal. 1994) (en banc) (permitting in-house counsel to sue client for retaliatory discharge). 
client, rather than the attorney, bears the financial repercussions resulting from the client's improper behavior. Although such a cause of action would not alleviate the emotional pressures that an attorney may face, the added financial security may induce the attorney to fulfill her responsibilities under the reporting requirement.

Despite the dilemma that in-house counsel face, a court may refuse to recognize claims of retaliatory discharge for attorneys fired for upholding ethics codes, thus leaving an attorney with no legal recourse. ${ }^{55}$ The primary obstacle preventing an attorney from bringing a retaliatory discharge action against a former employer is the presumption that employment contracts are terminable at-will: ${ }^{56}$

Since the end of the nineteenth century, state and federal courts have presumed that employees are terminable at-will and can be fired "for good cause, for no cause, or even for cause morally wrong, without [the employer] being thereby guilty of legal wrong." Conversely, employees have the reciprocal right to quit at any time. The at-will presumption, combined with the constitutional protection of freedom of contract in other labor cases at the beginning of the century, made it nearly impossible for an employee to rebut the at-will presumption. ${ }^{57}$

Thus, the at-will doctrine allows either the employer or the employee to terminate an employment contract without just cause. ${ }^{58}$ The employer is legally entitled to fire an attorney for fulfilling her ethical duties, no matter how unfair such a dismissal may seem. It is unclear whether or not the at-will doctrine applies to situations in whicl a law firm fires an attorney for complying with rules of ethical conduct. ${ }^{59}$ However, with few exceptions, courts

55. See Balla v. Gambro, Inc., 584 N.E.2d 104, 108 (Ill. 1991). For a survey of judicial decisions addressing this issue, see Sara A. Corello, In-House Counsel's Right to Sue For Retaliatory Discharge, 92 COLUM. L. REV. 389 (1992).

56. Murphy v. American Home Prods. Corp., 448 N.E.2d 86, 89 (N.Y. 1983) (noting the "long settled rule that where an employment is for an indefinite term it is presumed to be a hiring at will which may be freely terminated by either party at any time for any reason or even for no reason" (citations omitted)).

57. Corello, supra note 55, at 390-91 (citations omitted).

58. Id.

59. See Nordling v. Northern States Power Co., 478 N.W.2d 498, 499, 502 (Minn. 1991) (suggesting that law firm employee would not be barred from bringing suit for wrongful discharge as it would not interfere with the attorney-client relationship); Wieder v. Skala, 609 N.E.2d 105, 109 (N.Y. 1992) (permitting attorney terminated for complying 
strictly enforce the at-will doctrine when the employer is also the attorney's client. ${ }^{60}$

The rationale behind denying an attorney recovery for retaliatory discharge against a client is based primarily on the concern that a cause of action might compromise the trust that constitutes the foundation of the relationship between an attorney and her client. There is a common understanding based on trust between attorney and client that encourages open and candid communication: "[T]he danger exists that if in-house counsel are granted a right to sue their employers, . . . employers might . . . limit their communication with their in-house counsel." ${ }^{61}$ As one court noted,

At the heart of the attorney-client relationship is the element of trust. If the relationship is to work, the client must confide in the attorney, trusting that the attorney will keep confidences and will ably perform. If the client loses this confidence, whether justifiably or not, the client must be able, without penalty, to end the relationship. ${ }^{62}$

Courts are also reluctant to abandon the at-will doctrine to prevent in-house counsel from shifting the costs of enforcing legal ethics codes onto clients. ${ }^{63}$ As the Illinois Supreme Court noted, "[I]t would be inappropriate for the employer/client to bear the economic costs and burdens of their in-house counsel's adhering to their ethical obligations under the Rules of Professional Conduct." 64

with ethics codes to recover on an implied-in-law contract theory).

60. See Balla v. Gambro, Inc., 584 N.E.2d 104, 109 (Ill. 1991) (holding in-house counsel do not have a claim of retaliatory discharge); Nordling, 478 N.W.2d at 501 (holding status as an in-house attorney did not entitle plaintiff to breach of contract damages). But see General Dynamics Corp. v. Rose, 876 P.2d 487, 490 (Cal. 1994) (en banc) (holding both in-house counsel and non-attorney employees are entitled to advance retaliatory discharge claims).

61. Balla, 584 N.E.2d at 109. But see General Dynamics, 876 P.2d at 487 (discussed infra Part II).

62. Nordling, 478 N.W.2d at 501.

63. Costs incurred by attorneys resulting from reporting unethical conduct can be high. For example, the losses of the attorney in Wieder v. Skala, 609 N.E.2d 105 (N.Y. 1992), included lost wages and $\$ 30,000$ in additional expenses. Christopher Senior, Does New York's Code of Professional Responsibility Force Lawyers to Put Their Jobs on the Line? A Critical Look at Wieder v. Skala, 9 HOFSTRA LAB. L.J. 417, 421 (1992).

64. Balla, 584 N.E.2d at 110. 
In Herbster v. North American Co. for Life \& Health Insurance, the court indicated that a plaintiff may be allowed to bring a claim for wrongful discharge against a former employer if the discharge "was in contravention of a clearly mandated public policy." " In its application, however, this exception to the at-will doctrine may afford little relief to the wrongfully discharged attorney. The Herbster court held that the public policy considerations were not great enough to allow a cause of action where the attorney was discharged for refusing to destroy discovery information. ${ }^{66}$ In Balla v. Gambro, the same court refused to find a cause of action for an attorney who was dismissed for reporting his employer's attempt to distribute defective, and potentially lifethreatening, kidney dialyzers. ${ }^{67}$ Although recognizing the importance of protecting the public from harm, the court found that the public policy concerns were adequately safeguarded by the Illinois Rules of Professional Conduct requiring an attorney to report illegal conduct. ${ }^{68}$ If the public interest in saving lives is insufficient to overcome the presumption of an at-will employment contract, it is difficult to imagine a situation in which the public policy concerns would be sufficient to allow an attorney to recover for wrongful discharge.

There have been circumstances in which courts have permitted an attorney to recover for wrongful discharge. For instance, in Mourad v. Automobile Club Insurance Ass'n, an attorney was permitted to recover for breach of contract after he was constructively discharged following his refusal to violate the Code of Professional Conduct. $^{69}$ However, Mourad is an exception to the rule; the court found that the employer had violated an implied covenant in the company policy manual. ${ }^{70}$ Aside from those situations when

65. Herbster v. North Am. Co. for Life \& Health Ins., 501 N.E.2d 343, 344 (Ill. 1986), appeal denied, 508 N.E.2d 728 (Ill. 1987), cert. denied, 108 S. Ct. 150 (1987) (citations omitted).

66. See id. at 348.

67. See Balla, 584 N.E.2d 104, 110 (IIl. 1991).

68. Id. at 108 .

69. See Mourad v. Automobile Club Ins. Ass'n, 465 N.W.2d 395, 397 (Mich. 1991), appeal denied, 478 N.W.2d 443 (Mich. 1991).

70. See id. at 398. The exception in Mourad suggests that an attorney may be able to anticipate the need to bring a suit against a former client by incorporating the right to sue into an employment contract. However, it is unlikely that such a clause would be upheld. In Nordling v. Northern States Power Co., 478 N.W.2d 498, 501 (Minn. 1991), the court found that the client's right to fire an attorney is implied in every attorney- 
an attorney can rely on a promise found in a policy manual, it is difficult for an attorney to bring an action for retaliatory discharge against a former client.

\section{ApPLying the Missing LANGUAGe OF Responsibility to THE DILEMMA OF IN-HOUSE COUNSEL}

Although a survey of the cases addressing an attorney's right to sue a client demonstrates that the likelihood of bringing a successful action against a former client may be small, a recent decision by the California Supreme Court suggests that such a cause of action may be possible, at least in California. In General Dynamics Corp. v. Rose, the California Supreme Court departed from the traditional view by deciding that the dilemma confronting in-house counsel justified permitting a cause of action against the client for wrongful termination. ${ }^{71}$ The California Supreme Court's holding in General Dynamics is inconsistent with the leading case, Balla v. Gambro, Inc., in which the Illinois Supreme Court denied in-house counsel the right to sue a client for retaliatory discharge. ${ }^{72}$ The General Dynamics court and the Balla court were confronted with similar factual situations, yet arrived at different conclusions. Although reconciliation of Balla and General Dynamics may be difficult, Glendon's responsibility analysis may provide a framework in which to determine which court reached the optimal solution. Within such a framework, the decision that valued responsibility above rights may be viewed as the decision most likely to encourage ethical behavior within the legal community.

A. Balla v. Gambro, Inc. and General Dynamics Corp. v. Rose

At the time that the facts of Balla arose, Gambro, Inc. (Gambro) was a U.S.-based company that distributed kidney dialysis machines manufactured by Gambro's German counterpart. ${ }^{73}$ The distribution of these machines was regulated by various federal agencies, including the United States Food and Drug Administration (FDA) ${ }^{74}$ Roger Balla was an attorney serving Gambro as

client contract. Courts may be reluctant to permit parties to contract around this right.

71. See General Dynamics Corp. v. Rose, 876 P.2d 487, 490 (Cal. 1994) (en banc).

72. Balla v. Gambro, Inc., 584 N.E.2d 104, 108 (Ill. 1991).

73. Id. at 105 .

74. Id. 
its director of administration, general counsel, and manager of regulatory affairs. ${ }^{75}$

In 1985, Gambro's German counterpart, in shipping certain dialyzers to Gambro, included a description of that shipment. ${ }^{76}$ Based on the information provided by the German company, Balla advised Gambro to reject the shipment for failure to comply with FDA regulations. ${ }^{7}$ The president of Gambro decided to accept the shipment despite Balla's advice. Balla reiterated that acceptance of the shipment would violate FDA regulations and further informed the president of Gambro that he would do whatever was necessary to prevent the sale of the dialyzers. ${ }^{78}$ Balla was subsequently fired, at which time he reported the shipment to the FDA. $^{79}$ The FDA seized the equipment and found that the shipment was "adulterated" and in violation of federal law.

Subsequently, Balla brought suit against his former employer, Gambro, based on the tort theory of wrongful discharge. ${ }^{81}$ The Illinois Supreme Court found that Balla believed that the sale of the adulterated dialyzers could result in serious injury or death to kidney patients. ${ }^{82}$ Moreover, the court stated that " $[t]$ here is no public policy more important or more fundamental than the one favoring the effective protection of the lives and property of citizens." ${ }^{\text {"83 }}$ However, the court denied Balla recovery based primarily on the court's recognition of the value of preserving the sanctity of the attorney-client relationship and the importance of the at-will doctrine in the attorney-client context. ${ }^{84}$

Andrew Rose served as corporate in-house counsel for a different U.S. corporation, General Dynamics' Pomona plant. ${ }^{85}$ Having worked for General Dynamics for approximately fourteen years, Rose, like Balla, was not terminated for incompetence. ${ }^{86}$
75. Id. at 106 .
76. $I d$.
77. Id.
78. $I d$.
79. Id.
80. Id.
81. Id.
82. Id. at 107 .
83. Id. at 107-08 (quoting Palmateer v. International Harvester Co., 421 N.E.2d 876, 879 (Ill. 1981)).
84. Id. at $107-13$.
85. General Dynamics Corp. v. Rose, 876 P.2d 487, 490 (Cal. 1994) (en banc).
86. Id. Rose believed that his termination was not based on "any loss of confidence 
Instead, according to Rose, he was terminated following "an attempt by company officials to cover up widespread drug use among the General Dynamics workforce, a refusal to investigate the mysterious 'bugging' of the office of the company's chief of security, and the displeasure of company officials over certain legal advice Rose had given them" regarding the company's actions. ${ }^{87}$ Although there is no evidence that indicates Rose actually reported the conduct of his client, Rose, like Balla, "spearheaded an investigation into employee drug use" and protested "the company's failure to investigate the bugging of the office of the chief of security" and violations of the federal Fair Labor Standards Act. ${ }^{88}$ In granting Rose the right to recover, the Supreme Court of California specifically declined to follow Balla and held that "there is no valid reason why an in-house attorney should not be permitted to pursue ... [a] claim in the same way as the nonattorney employee." 89

\section{B. Who Is Responsible?}

In applying Glendon's responsibility framework to the disparate outcomes in Balla and General Dynamics, it is important to begin by defining the responsibilities that an attorney serving as in-house counsel should be expected to fulfill. Clearly, both Balla and Rose should have been expected to "provide competent representation" to their clients. ${ }^{90}$ This representation includes, among other duties, "the fiduciary duty an attorney owes to a client." 91 However, more pertinent in the present situation, both Balla and Rose were responsible for protecting the confidences of the client. ${ }^{92}$ The scope of this responsibility extends beyond just the interests of the client as can be seen by examining the rationale be-

in his legal ability or commitment" to the company's interest. Id.

87. Id.

88. Id. at 491.

89. Id.

90. Model Rules of Professional Conduct Rule 1.1 (1992).

91. Balla v. Gambro, Inc., 584 N.E.2d 104, 108 (IIl. 1991).

92. MODEL RULES OF PROFESSIONAL CONDUCT Rule 1.6 (1992). 
hind the attorney-client privilege. ${ }^{93}$ The attorney-client privilege serves to encourage

full and frank communication between attorneys and their clients and thereby promote broader public interests in the observance of law and administration of justice. The privilege recognizes that sound legal advice or advocacy serves public ends and that such advice or advocacy depends upon the lawyer being fully informed by the client. ${ }^{94}$

Thus, in deciding which court arrived at the preferred outcome, it is important to determine whether the courts considered the attorneys' responsibilities to the client, the importance of attorneyclient confidences, and the broader public interests implicated by upholding the sanctity of the attorney-client relationship.

The Balla court, in denying the attorney the right to recover against his client, based its reasoning on the importance of upholding the attorney's responsibility to the client. In rejecting the attorney's claim, the court considered not only the purpose of the tort of retaliatory discharge, but also "the effect on the attorneyclient relationship that extending the tort would have." ${ }^{55}$ It refused to consider an intrusion into the sanctity of the attorneyclient relationship and supported its decision with strong responsibility language. ${ }^{96}$ In contrast, the General Dynamics court, while failing to permit the attorney to breach attorney-client confidentiality summarily, appeared to place a lower value on the attorneyclient relationship than the Balla court did. Instead, the General

93. The attorney-client privilege is distinguished from attorney-client confidences in the comments to the Model Rules of Professional Conduct:

The attorney-client privilege applies in judicial and other proceedings in which a lawyer may be called as a witness or otherwise required to produce evidence concerning a client. The rule of client-lawyer confidentiality applies in situations other than those where evidence is sought from the lawyer through compulsion of law. The confidentiality rule applies not merely to matters communicated in confidence by the client but also to all information relating to representation, whatever its source. A lawyer may not disclose such information except as authorized or required by the Rules of Professional Conduct or other law.

Id. Rule $1.6 \mathrm{cmt} .5$ (1992).

94. Balla, 584 N.E.2d at 110 (quoting Upjohn Co. v. United States, 449 U.S. 383, 389 (1981)).

95. Id. at 108 .

96. Id. at 109 ("In-house counsel must abide by the Rules of Professional Conduct."); see also id. at 110 ("However difficult economically and perhaps emotionally it is for in-house counsel[,] . . . we refuse to allow in-house counsel to sue their employer-client."); id. ("All attorneys know or should know that ... they will have to forgo economic gains in order to protect the integrity of the legal profession."). 
Dynamics court applied a balancing test accommodating the conflicting values of the attorney-client relationship and the attorney's interests in secure employment. ${ }^{97}$ Thus, at least in terms of the responsibility that an attorney owes with respect to the confidences given to the attorney by the client, the Balla court's reasoning more closely resembles the responsibility-based approach advocated by Glendon: it defined the responsibility, focused the language of its decision on that responsibility, and even took the analysis further by requiring the attorney to fulfill his responsibility to his client.

Other responsibilities owed by attorneys to clients beyond protecting the confidentiality between attorney and client further suggest that Balla more closely adheres to Glendon's principles. For instance, according to Glendon, economics should not be a governing principle in public dialogue: "Our rights-laden public discourse easily accommodates the economic, the immediate, and the personal dimensions of a problem, while it regularly neglects the moral, the long-term, and the social implications." 98 The Balla court appears to base its decision on principles consistent with Glendon's approach, holding that "it would be inappropriate for the employer/client to bear the economic costs and burdens of their in-house counsel's adhering to their ethical obligations under the Rules of Professional Conduct." 99 Although taking into account the interests of the client, the Balla court clearly rejected the proposition that the attorney should prevail because of economic hardship. Instead, the court required the attorney to uphold his responsibilities and bear the costs of "obeying the Rules of Professional Conduct." 100

In stark contrast, the General Dynamics court explicitly accepted the argument that denial of the right to sue would impose an undue financial burden on the attorney. ${ }^{101}$ The court found that Rose was a career-oriented employee and had certain financial expectations that were undermined by the client. ${ }^{102}$ Based on these findings, the court held in favor of Rose. And by relying on

97. General Dynamics Corp. v. Rose, 876 P.2d 487, 490 (Cal. 1994) (en banc).

98. GLENDON, supra note 1 , at 171.

99. Balla, 584 N.E.2d at 110 .

100. Id.

101. General Dynamics, 876 P.2d at 502.

102. Id. at $495-96$. 
these financial arguments, General Dynamics appears to contradict Glendon's responsibility principles.

At this juncture, it is possible to argue that the General Dynamics court's holding, in its apparent rejection of the responsibilities owed the client, is nevertheless correct. Although it did not appear to value the confidential nature of the attorney-client relationship to the same extent as the Balla court, the General Dynamics court did take into account the attorney's responsibility to the public and to the legal profession. It found that both groups have an interest in deterring unethical behavior of clients, ${ }^{103}$ which, in General Dynamics, included illegal bugging and widespread drug use. ${ }^{104}$ Implicit in the court's decision was a recognition that permitting a cause of action would increase the likelihood that a client's unethical behavior would be reported. However, although it is true that the General Dynamics court took the responsibility owed to the public into account, the Balla court also required an attorney to fulfill this responsibility. As the Balla court stated, "The public policy[,] . . . that of protecting the lives and property of citizens, is adequately safeguarded," because Balla is required to report Gambro's intention to sell adulterated dialyzers under the Illinois version of Rule 1.6. ${ }^{105}$ The court continued, "In-house counsel do not have a choice of whether to follow their ethical obligations as attorneys licensed to practice law, or follow the illegal and unethical demands of their clients. In-house counsel must abide by the [Illinois] Rules of Professional Conduct."106 And the Rules of Professional Conduct require an attorney to report conduct that would result in death or serious injury. ${ }^{107}$

103. Id. at $497-98,501-02$.

104. Id. at 490 .

105. Balla v. Gambro, Inc., 584 N.E.2d 104, 108-09 (Ill. 1991). It is interesting to note that in Illinois, an attorney is required to report the conduct of a client that may result in serious injury or death. However, in California, the duty is permissive: an attorney may report the conduct but is not absolutely required to do so. Compare CAL. EvID. CODE $\S 956.5$ (West Supp. 1995) (An attorney may reveal confidential communications "if the lawyer reasonably believes that disclosure ... is necessary to prevent the client from committing a criminal act that the lawyer believes is likely to result in death or substantial bodily harm.") with ILL. R.P.C. 1.6(b) (1990) ("A lawyer shall reveal information about a client to the extent it appears necessary to prevent the client from committing an act that would result in death or serious bodily harm." (emphasis added)). See supra note 45 and accompanying text.

106. Balla, 584 N.E.2d at 109.

107. Id. (citing ILL. R.P.C. 1.6(b) (1990)). 
Thus, although the General Dynamics court considered the interests of the public, the Balla court required the attorney to fulfill his responsibilities to the public, to the legal profession, and to the client; Balla required the attorney to protect the public from harm and prevented the attorney from shifting the costs to the client.

Not only did the Balla court take into account responsibilities owed to the client, the public, and the legal profession, but the court also explicitly repudiated the rights-based approach put forth by the attorney. By suing under a retaliatory discharge theory, the attorneys in both Balla and General Dynamics were attempting to protect their rights to employment with the particular clients. In fact, the Balla court framed the attorney's cause of action in terms of a rights-based action by noting that the attorney sought "a right to sue ... employers in tort for retaliatory discharge." 108 However, the Balla court rejected this right by denying the attorney a cause of action and declined to extend the availability of a retaliatory discharge action to in-house counsel. ${ }^{109}$ In contrast, General Dynamics did not reject the attorney's rights-based approach. Instead, the court recognized that the attorney had a strong interest in maintaining his employment with the company. Pivotal factors in the court's decision included the fact that "the plaintiff was hired as a 'career oriented' employee with an expectation of permanent employment, provided his performance was satisfactory; that he was promised job security and substantial retirement benefits; [and] that he regularly received outstanding performance reviews, promotions, salary increases, and commendations ...."110 And these factors defined the "rights" that, according to the court, were impermissibly abridged by the client. Thus, the General Dynamics court appeared to reject the responsibility that the attorney owed to the client and instead upheld the rights of the attorney. In contrast, the Balla court, by rejecting the attorney's assertion of his rights and requiring that he uphold his responsibilities to the client and the public at large, appears to adhere more closely to Glendon's responsibility-based approach than does the General Dynamics court.

108. Id. at 109-10.

109. See id. at 110 .

110. General Dynamics Corp. v. Superior Court, 876 P.2d 487, 495 (Cal. 1994) (en banc). 


\section{RESPONSIBILITY AND PERSPECTIVE}

An examination of the holdings in Balla and General Dynamics under a responsibility framework suggests that Balla is more consistent with the "responsible" approach outlined by Glendon. Although this responsibility-based analysis appears to offer a plausible resolution to the disparities between Balla and General Dynamics, this analysis has arrived at a conclusion contrary to the weight of scholarly authority. Following the Illinois Supreme Court's holding in Balla, legal journals were flooded with in-depth analyses of whether an attorney should be granted the right to sue a client. As the General Dynamics court noted, "[D]espite the fact that no more than a handful of such cases have been reported nationally, scholarly comment on the issues raised in retaliatory discharge tort claims by in-house counsel is disproportionately large." 111 Such extensive commentary has resoundingly opposed the Balla court's decision to deny in-house counsel the right to sue. ${ }^{112}$ The strength of the opposition to the Balla decision raises questions as to the validity of the finding that the decision is supported by Glendon's analysis. Furthermore, the fact that the weight of scholarly authority so strongly opposes Balla, while Glendon's analysis suggests that it is the correct outcome, casts doubt on the practical applicability of Glendon's approach to the situations faced by Balla and Rose.

\section{A. The Rationale Behind Balla}

Before addressing whether Glendon's approach produces the correct result, it is important to recognize that the rationale employed by the Balla court may have been founded on misplaced assumptions. For instance, the court was concerned that permitting recovery by in-house counsel might compromise the trust that constitutes the foundation of the relationship between an attorney

111. Id. at 500 n.5 (citations omitted).

112. See Elliott M. Abramson, Why Not Retaliatory Discharge for Attorneys: A Polemic, 58 TENN. L. REV. 271, 278 (1991); Corello, supra note 55, at 405; Giesel, supra note 39, at 558-62; Raymis H.C. Kim, Comment, In-House Counsel's Wrongful Discharge Action Under the Public Policy Exception and Retaliatory Discharge Doctrine, 67 WASH. L. REV. 893, 913 (1992). But see Steven S. Gensler, Note, Wrongful Discharge for In-House Attorneys? Holding the Line Against Lawyers' Self-Interest, 1992 U. ILL. L. REv. 515 (1992) (arguing that discharge suits undermine the adversarial legal system which depends on open communications between attorney and client). 
and her client. There is a common understanding based on trust between attorney and client that encourages open and candid communication. As the Balla court noted, "[T]he danger exists that if in-house counsel are granted a right to sue their employers, ... employers might . . . limit their communication with their in-house counsel." 113 Although there is some validity to this argument, other factors may already limit a client's ability to engage in completely candid communication with an attorney. For example, Rule 1.6 of the Model Rules of Professional Conduct permits an attorney to report attorney-client communications in order to prevent a criminal act that may result in death or bodily harm. ${ }^{114}$ Courts have recognized that attorneys' actions in revealing client confidentialities pursuant to this provision may make clients "naturally hesitant to rely on in-house counsel for advice regarding . . . potentially questionable conduct." ${ }^{115}$ Thus, factors that serve to "chill" attorney-client communications already exist and are, in fact, permitted by the legal profession's ethics codes. Thus, if a client is already hesitant to seek out counsel regarding illegal activity because attorneys can reveal client information pursuant to Rule 1.6, it makes little sense to assume that the right of an attorney to sue would suddenly create an impermissibly burdensome chilling effect on attorney-client communications. Moreover, protection of the attorney-client relationship may be inappropriate when it is the client, and not the attorney, who is abusing the relationship.

Protection of the attorney-client relationship is not the only basis on which courts have been reluctant to extend the tort of retaliatory discharge to in-house counsel. For instance, the Balla court reasoned that in-house counsel should not be allowed a cause of action against a client in order to avoid shifting the costs of enforcing legal ethics codes onto clients: "116 "[I]t would be inappropriate for the employer/client to bear the economic costs and burdens of their in-house counsel's adhering to their ethical obligations under the Rules of Professional Conduct." 117 Again, this rationale disregards the fact that the employer's conduct, not the

113. Balla, 584 N.E.2d at 109.

114. MOdel Rules of Professional Conduct Rule 1.6(b)(1) (1991). In some states, disclosure may be required. See supra note 45 .

115. Balla, 584 N.E.2d at 109.

116. See supra text accompanying notes $63-64$.

117. Balla, 584 N.E.2d at 110. 
attorney's, created the ethical dilemma. ${ }^{118}$ Without the protection of the right to sue, it is the attorney who must inevitably pay for the client's unethical conduct.

Moreover, by refusing to recognize the attorney's claim, Balla would force an attorney to choose between her livelihood and her ethical obligations to the legal community. If she chooses to report the conduct as required, she may lose her job; if she chooses not to report the conduct, she has breached the ethics codes of her profession. Denial of the right to sue would also deprive an attorney of the opportunity to prove that the dismissal was wrongful, a factor that may be critical in procuring alternate employment. By placing attorneys in this dilemma, the Balla court discourages attorneys from making ethical choices consistent with community standards.

\section{B. Defining Glendon's Responsibility}

Unfortunately, criticism of the court's decision to place a premium on protection of attorney-client confidences and to disregard the financial burden placed on in-house counsel does not explain why a responsibility-based analysis creates a result so contrary to the legal commentary. However, the foregoing analysis does demonstrate a number of assumptions made by the Balla court that affect the validity of a responsibility-based analysis. In particular, the Balla court assumed that because of the sanctity of the attorney-client relationship, its analysis should proceed under the assumption that, above all, the attorney is responsible to the client. Although this assumption may be properly based on the ethics codes governing the legal profession, ${ }^{119}$ it is possible that a responsibility-based approach would not focus on the responsibility of the attorney. Glendon might ask the question asked by other scholars, namely, "Why should the 'confidentiality' between the attorney and the client be blindly sanctified when it can be employed as a shield behind which corporations can coerce attorneys into wrongdoing? Why should there be confidentiality for a wrongdoer or those scheming to do wrong?" ${ }^{120}$ Thus, under a responsi-

118. See id. at 114 (Freeman, J., dissenting).

119. See Model Rules of Professional Conduct Preamble §§ 1-2 (1992) (indicating that "a lawyer is a representative of clients," id. $\S 1$, who "zealously asserts the client's position, ... . [and] seeks a result advantageous to the client," id. § 2).

120. Abramson, supra note 112 , at 286. 
bility-based approach, perhaps the analysis should focus on the responsibility of the client, rather than that of the attorney. Furthermore, it is possible to focus on the responsibility that society at large may owe the attorney. Considering that the attorney may be placed in such a difficult dilemma, it is reasonable to expect society, which will benefit from the disclosure of a client's undesirable conduct, to aid the attorney in making the ethical decision.

By considering the responsibility owed to the attorney, rather than from the attorney, the analysis of Balla and General Dynamics changes, as can be seen by examining how the responsibility to the attorney can be fulfilled. Grace Giesel has suggested employing several measures in order to consider the responsibility to the attorney. She suggests that "[s]ociety can improve the plight of inhouse counsel ... [by modifying] in-house counsel's calculus when faced with an ethical demand of client-alienating behavior... [and by lessening] the sacrifice that an individual in-house attorney makes when choosing the ethical path." ${ }^{121}$ In particular, granting an attorney the right to sue would lessen the detrimental impact of ethical decisionmaking on the attorney. The attorney would not be forced to sacrifice herself financially because she would no longer be required to bear the costs of upholding the ethics requirements. And by granting the right to sue the client based on the responsibility owed to the attorney, the result would be consistent not with Balla, but with the more intuitively correct holding in General Dynamics.

This result would be preferable because it would represent "[r]ecognition of the pressures upon in-house counsel." $122 \mathrm{Al}-$ though it would not prevent a client from discharging an attorney, the attorney would no longer be forced to bear the financial burden of upholding the legal ethics codes. Whereas under Balla, the client was rewarded for unethical behavior because of her ability to shift the costs to the attorney, ${ }^{123}$ under General Dynamics, a client may instead be required to compensate the attorney for any financial loss resulting from wrongful discharge. Not only would the opportunity for exploitation be lessened, but the attorney would also be given the opportunity to clear her name, thereby aiding the attorney in procuring future employment by decreasing

121. Giesel, supra note 39, at 538 (citations omitted).

122. Abramson, supra note 112, at 279.

123. Giesel, supra note 39 , at 538-39. 
the stigmatic effect of being fired. Moreover, the elimination of financial and career disincentives indicates that the client must take financial responsibility for her actions; it also increases the likelihood that an attorney faced with the difficult decision of whether to report the unethical conduct of her client will abide by the ethical rules of the legal profession. ${ }^{124}$

By shifting the focus of Glendon's responsibility-based analysis to the client, incentives would be in place to encourage, rather than discourage, ethical behavior. First, permitting the attorney to sue for wrongful discharge would shape the behavior of the attorney serving as in-house counsel. When faced with the decision of whether to report unethical conduct, she would no longer be pressured by financial considerations and could instead follow the ethics codes without fear of unredressable repercussions. Beyond shaping the behavior of individual attorneys, allowing an attorney a cause of action may also improve the ethical behavior of the clients. Requiring the client to make financial compensation for the wrongful discharge may discourage that client from discharging attorneys who report unethical conduct. A client is also less likely to engage in unethical behavior when it is probable that an attorney within the corporation will report that behavior.

Of course, permitting attorneys to bring a cause of action following a wrongful dismissal does not eliminate all of the pressures that encourage attorneys to make unethical choices. Although an attorney may receive financial compensation once she has been fired, she will not be reinstated to her former job. In addition, there is no guarantee that the damages awarded by the court will adequately compensate the attorney for her losses. Nor does the decision alleviate the difficulties an attorney must face when seeking future employment. A corporation may be reluctant to hire an attorney who was fired, even though the dismissal was wrongful. For example, a corporation that does not adhere to ethical standards will decline to hire an attorney who is likely to blow the whistle on its conduct. Even an ethical corporation may be reluctant to hire an attorney who did not show a high level of loyalty in her previous job. However, the plight of in-house coun-

124. Although General Dynamics encourages attorneys to report the unethical conduct of a client, it is important to note that it is unclear whether such a disclosure would be required by law. See supra text accompanying notes 45 and 105 . 
sel will be significantly improved, and both society and the client will have taken the responsible approach.

Focusing instead on the responsibility of the client and society at large, this version of the responsibility-based approach would create results more consistent with both scholarly commentary and basic equitable principles. The attorney who fulfills her responsibility to society by reporting misconduct would not be unduly penalized, and the client that under Balla would reap the benefits would be held responsible for her prior unethical conduct. While changing the perspective would provide a more equitable result, it also demonstrates a critical weakness in Glendon's analysis. Glendon, in discussing rights-based dialogue, notes that "[i]n truth, there is very little agreement regarding which needs, goods, interests, or values should be characterized as 'rights' ...."125 However, she fails to explain why the difficulties inherent in defining rights would not exist in defining responsibilities. As Professor David Abraham noted, "Like Communitarians generally, Glendon wants a law more closely linked to morality-but whose? Which community or religious faith should provide the requisite ethical base-and to whom?" 126 The definitional problems can be seen by examining General Dynamics and Balla. When focusing on the responsibility of the attorney, the analysis supports the result in Balla. However, when the analysis focuses on the responsibility of the client and society, General Dynamics appears to be the most logical result. It is difficult to understand how a responsibilitybased approach can be of practical use when the definitional problems create such disparate results.

Application of Glendon's approach to the dilemma facing inhouse counsel reveals other weaknesses in Glendon's approach, such as her failure to take practicalities into account. Not only does Glendon fail to tackle the definitional problems inherent in a responsibility-based approach, but she also appears to disregard the fact that "not all problems can be solved satisfactorily within their embedded social contexts." 127 For instance, it is unavoidable that, for many in-house attorneys, the client has a great advantage over the attorney. First, the client holds all of the financial power in the relationship: "Loss of the attorney's one and only client

125. GLENDON, supra note 1 , at 16 .

126. Abraham, supra note 29 , at 957.

127. Barton, supra note 31 , at 809 . 
reduces profitability to zero." 128 While the attorney's loss of her job could create financial havoc, the client need only hire another attorney to replace the fired attorney. Moreover, the power that an attorney may have as a virtue of her position as in-house counsel may be overestimated:

First, it is not clear that in-house attorneys are more powerful than other employees. In-house counsel's access to confidential information (and resulting power against the employer) is not unique. Although in-house counsel is usually exposed to more areas of operations, non-lawyers also have access to extremely sensitive information; this assumption underlies whistleblower statutes that encourage reporting by employees. However, if the court is assuming that professional employees have greater job security because of their ability to blackmail their employer by threatening to reveal embarrassing information, attorneys are at a disadvantage. Unlike other employees, attorneys are bound by the ethical codes not to reveal information obtained from their client-employer. Therefore, in-house attorneys are at least as vulnerable as other middle- and senior-level managers who do have standing to sue. ${ }^{129}$

Despite the potential imbalance between attorney and client, Glendon does not offer a solution as to how this imbalance should be incorporated into her responsibility approach. Nor does she offer a means to address those situations in which, because of a power imbalance, it is necessary for an individual to exert her rights. As Professor Thomas Barton has noted, "Retaining a residual rights talk thus allows for a dialogue of protection that we may sometime value as much or more than community traditions." ${ }^{130}$ If the attorney relies solely on responsibility language, the result may be loss of employment. Moreover, it is difficult to understand how responsibility language would be sufficiently powerful to prevent unethical conduct from a client who would later fire an attorney for her ethical behavior.

Finally, as Glendon's approach is based on the use of responsible language, she presupposes that the resulting dialogue will

128. Giesel, supra note 39, at 536 ("Exalted statements that most in-house counsel possess such high ethical standards that economic pressure cannot sway them, no matter how great, are, unfortunately, suspect.").

129. Corello, supra note 55, at 404-05 (citations omitted).

130. Barton, supra note 31 , at 813 . 
actually reach the intended audience. In the situation of in-house counsel, the attorneys and the clients may not be involved in the dialogue. Due to the nature of the position, in-house attorneys are typically very isolated from other members of the legal profession. Whereas members of law firms are surrounded by other members of the Bar, in-house counsel may be the sole attorney on staff. ${ }^{131}$ Thus, although decisions such as Balla may be full of responsibility language, the fact that in-house counsel may be isolated from the legal profession, and too busy handling corporate matters to follow every decision handed down by the courts, reduces the likelihood that the court's language can shape behavior. It is difficult to imagine the beneficial impact of the language of responsibility when that language may not even be heard.

\section{CONCLUSION}

Glendon, in her exploration of society's fascination with rights talk, provides a useful framework for the realization that our culture has become obsessed with rights and has failed to include adequately a language of responsibility into American jurisprudence. However, the shortcomings in her theory could potentially undermine the very goal that she is trying to achieve: the creation of a more responsible society. Glendon's theory fails to offer tangible guidance to courts confronted with situations in which both sides of a dispute have adverse interests yet each side owes a duty to the other; no framework exists for determining whose responsibility should govern. Without a hermeneutic for reconciling the definitional problems inherent in Glendon's approach, application of her theory can lead to the inequitable result of Balla, where the court assigned responsibility, and hence punishment, to the ethical attorney and assigned rights, and hence rewards, to the unethical client. Unless courts, or Glendon herself, can develop a principled theory to determine whose responsibility trumps when more than one party should have responsibility, the courts, in their efforts to enforce the responsibilities an attorney owes a client, will continue

131. This isolation can affect the behavior of in-house counsel: "In addition to the substantial economic disincentive, the secluded nature of the in-house situation reduces the malpractice threat and the chance of independent reports to the Bar." Giesel, supra note 39 , at 537 . 
to allow "a corporate employer to discharge its in-house counsel ... . without fear of any sanction ... [, thereby giving] the assistance and protection of the courts to scoundrels." 132

132. Balla v. Gambro, Inc., 584 N.E.2d 104, 114 (Ill. 1991) (Freeman, J., dissenting). 
。 